\title{
ВПЛИВ СТИМУЛЯЦІї ОХОТИ ТА СИНХРОНІЗАЦІї ОВУЛЯЦІї НА МОРФО-БІОХІМІЧНІ ПОКАЗНИКИ КРОВІ ГОЛШТИНСЬКИХ КОРІВ
}

\author{
Гончар Альона Олександрівна \\ кандидат сільськогосподарських наук \\ Дніпровський державний аграрно-економічний університет \\ ORCID: 0000-0001-9743-3248 \\ E-mail: aquazz@ukr.net
}

\begin{abstract}
Стаття містить результати досліджень на предмет змін гематологічних та біохімічних показників крові до та після екзогенної гормональної стимуляції репродуктивної функції голштинських корів різного рівня продуктивності на промисловому комплексі у порівнянні із рефрерентною нормою. Морфо-біохімічні показники крові визначались спочатку перед початком схеми стимуляції охоти і синхронізації овуляції "Оvsуnch», а потім після неї. Формування дослідних груп проводили залежно від рівня їх добового надою: I група - 25-28 ке, II група (контрольна) - 30-35 ке, III - 40-45 ке. Відбір зразків крові проводили з підхвостової вени у здорових корів через 15 діб після отелення (перед гормональною стимуляцією) та на 80 добу після отелення, - коли тварини вже отримали ін'єкиії гормоноподібних стимулюючих препаратів. Встановлено, що кількість еритроцитів у крові корів усіх піддослідних груп в період підготовчого періоду досліджень (до гормонального обробітку тварин) збільшується прямо пропориійно рівню їх молочної продуктивності. При чому, показник рівня гемоглобіну тварин в усіх піддослідних групах відповідав фізіологічній нормі. Екзогенне введення в організм голштинських корів гонадотропних речовин на ранній стадії післяродового періоду (10-14 доба після отелення) не призводить до змін рівня їх морфологічних показників крові. Встановлено, що найвищий рівень кількості еритроцитів (8,10 Т/л) та лейкоцитів (9,0 2/л) у крові тварин III групи тварин, які мали добовий удій на рівні 41,0 кг молока. Кількісний вміст загального білку крові у тварин всіх піддослідних груп знаходився в межах фізіологічної норми, але найбільша його кількість (95,2 г/л) відмічена у зразках крові III групи тварин після гормональної стимуляції еструсу. В ией же час, рівень гемоглобіну у цих корів дорівнював 125,4 г/л, при вмісті загального білка крові - 95,2 г/л. Показники мінерального обміну у корів III групи вказують на вміст кальцію та фосфору на рівні 3,24 ммоль/л і 1,28 ммоль/л відповідно. Фізіолого-біохімічні процеси в організмі тварин всіх груп як до так і після стимуляиії охоти і синхронізації овуляиії в умовах промислового комплексу проходять без порушень, про що свідчить рефрерентний рівень АЛТ і АCT, а найвищий вміст трансаміназ відмічено у корів III групи після гормональної стимуляції.
\end{abstract}

Ключові слова: надій, стимуляція, синхронізація, загальний білок, еритроцити, кальцій фоссфор.

DOI: https://doi.org/10.32845/bsnau.Ivst.2020.2.7.

Постановка проблеми, аналіз останніх досліджень, актуальність та мета. Сучасні високоефективні технології виробництва продуктів тваринництва неможливі без глибокого розуміння фізіологічного стереотипу тварин $[1-3]$.

Багатотехнологічні операції суперечать еволюційно обумовленим характеристикам живого організму, що в кінцевому підсумку може призвести до «збою» відтворної функції. Світовий досвід показує, що молочне скотарство, незважаючи на всі наукові досягнення, має великі втрати від результативних помилок відтворення. На сьогодні вирішальна роль в подальшій інтенсифікації молочного скотарства належить динамічному вдосконаленню репродуктивної функції тварин до максимально виправданого рівня [4-6].

Зростаючі вимоги до системного і прогнозованого рівня реалізації потенціалу молочної продуктивності голштинських корів зумовлюють необхідність більш глибоких і комплексних досліджень в області регуляції їх репродуктивної функцції [7-9].

В інноваційних підходах ведення галузі молочного скотарства значуще місце відводиться методам корекції та стимуляції відтворювальної системи корів з застосуванням фармакологічних засобів і біологічно активних речовин [1315].

Молочна продуктивність $€$ вирішальним фрактором протягом усього післяпологового періоду корів. Численними дослідженнями встановлено, що у високопродуктивних корів

відзначається тривала післяпологова інволюція статевих органів, причиною чого є фізіологічний антагонізм між органами розмноження і молочною залозою [16-21].

У зв'язку з цим перспективним і затребуваним напрямком $€$ використання гормональної корекції 3 метою підвищення репродуктивної функції великої рогатої худоби і інтенсифікації відтворення стада.

Матеріали та методи досліджень. За мету досліджень було поставлено встановити динаміку гематологічних та біохімічних показників крові до та після екзогенної гормональної стимуляції репродуктивної функції голштинських корів різного рівня продуктивності на промисловому комплексі (табл. 1).

Дослідження крові проводили на тваринах 2-3 лактацій, які були сформовані у три групи по 5 голів у кожній. На 10-14 добу після отелення тварини I групи мали середньодобовий удій (25-28 кг), що характеризувало їх як низькопродуктивних. У цей же час у корів II (контрольної) групи удій знаходився на рівні 30-35 кг, що відносилося до середнього рівня продуктивності. У тварин III групи середньодобові удої знаходилися на рівні 40-45 кг, що характеризувало їх як високопродуктивних.

У здорових піддослідних корів на 15 добу після отелення, перед початком гормональної стимуляції та на 80 добу після неї з підхвостової вени відбирали кров для морфологічних та біохімічних досліджень. 
Схема досліджень біологічних субстратів піддослідних корів

\begin{tabular}{|c|c|c|}
\hline \multirow{2}{*}{ Група тварин (рівень удою, вік у лактаціях) } & \multicolumn{2}{|c|}{ Період досліду } \\
\hline & підготовчий, 15 діб & дослідний, 80 діб \\
\hline I, n=5 (низький удій) & \multirow{3}{*}{$\begin{array}{l}\text { Групування здорових новотільних тварин та } \\
\text { підготовка їх до осіменіння. Відбір крові }\end{array}$} & \multirow{3}{*}{$\begin{array}{l}\text { Гормональна стимуляція еструсу та синх- } \\
\text { ронізація овуляції. Штучне осіменіння. } \\
\text { Відбір крові }\end{array}$} \\
\hline II (контрольна, n=5 (середній удій) & & \\
\hline III, n=5 (високий удій) & & \\
\hline
\end{tabular}

Підрахунок кількості еритроцитів та лейкоцитів проводили у камері Горяєва (2004) [11].

Лейкоцитарну формулу визначали із застосуванням клавішного лічильника, для чого робили мазок крові на предметному склі відповідно до методики РомановськогоГімзи (2004) [11]. методом

Рівень гемоглобіну визначали геміглобінцианідним

Кольоровий показник крові визначали за формулою:

$X=3 \mathrm{Hb}$ (2/л) / три перші цифрри кількість еритроцитів в 1 мкл

де: $x$ - кольоровий показник (од);

$H b$ - кількість гемоглобіну (г/л)

Швидкість осідання еритроцитів (ШОЕ) підраховували за допомогою мікрометоду [10].

Загальний білок сироватки крові визначали рефрактометричним методом [11].

Кількість кальцію визначали з використанням комплексону Арсеназо III, а фоссфору - за допомогою проби з аскорбіновою кислотою [11]

Кількість глюкози визначали за кольоровою реакцією з орто-толуідіном, а рівень АЛТ та АСТ визначали за методикою Рейтмана-Френкеля [12].
Результати досліджень. Кров $є$ функціональним середовищем, за допомогою якого здійснюється зв'язок усіх органів і систем, а також регулюються різноманітні фуннцції живого організму. За змінами показників крові можна судити про функціональний стан тварини в цілому.

Дослідження реологічних властивостей крові голштинських корів різного рівня продуктивності дозволяють детально та об'єктивно охарактеризувати фуункціональний стан їх організму (табл. 2). Кількість еритроцитів, концентрація гемоглобіну та глюкози вказують на здатність лактуючого організму тварин швидко компенсувати втрачені поживні речовини та енергію.

Слід зазначити, що кількість еритроцитів у крові піддослідних корів до застосування гормональної стимуляції зростала відповідно до збільшення рівня їх молочної продуктивності. Так, у високопродуктивних тварин III групи цей показник складав у середньому 7,54 Т/л, в той час як у низько- та середньопродуктивних тварин I i II груп він становив відповідно 6,02 і 6,66 Т/л. Особливо важливо те, що кількість еритроцитів в усіх дослідних групах голштинів відповідала фізіологічній нормі. Тобто піддослідні тварини характеризувалися хорошим здоров'ям.

Морфологічні показники крові голштинських корів різного рівня продуктивності

Таблиия 2

\begin{tabular}{|c|c|c|c|c|c|}
\hline \multirow{3}{*}{$\begin{array}{c}\text { Група тварин та рівень } \\
\text { удою }\end{array}$} & Гемоглобін, г/л & Еритроцити, Т/л & $\begin{array}{c}\text { Кольоровий показник, } \\
\text { одиниць }\end{array}$ & ШОЕ, мм/год & Лейкоцити, Г/л \\
\hline & \multicolumn{5}{|c|}{ Фізіологічна норма } \\
\hline & $85-140$ & $5,5-8,0$ & $0,7-0,99$ & $0,5-5,0$ & $6,6-9,5$ \\
\hline \multicolumn{6}{|c|}{ Перед гормональною стимуляцією } \\
\hline $\mathrm{I}, \mathrm{n}=5$ & $118,20 \pm 2,180$ & $6,02 \pm 0,077$ & $0,88 \pm 0,007$ & $1,60 \pm 0,358$ & $7,70 \pm 0,063$ \\
\hline II (контрольна), n=5 & $119,60 \pm 1,081$ & $6,66 \pm 0,046$ & $0,85 \pm 0,007$ & $2,80 \pm 0,335$ & $8,24 \pm 0,096$ \\
\hline III, $n=5$ & $121,80 \pm 0,716$ & $7,54 \pm 0,201$ & $0,84 \pm 0,005$ & $2,00 \pm 0,400$ & $8,44 \pm 0,046$ \\
\hline \multicolumn{6}{|c|}{ Після гормональної стимуляції } \\
\hline $\mathrm{l}, \mathrm{n}=5$ & $123,60 \pm 0,510$ & $7,90 \pm 0,100$ & $0,85 \pm 0,005$ & $3,20 \pm 0,663$ & $8,54 \pm 0,051$ \\
\hline II (контрольна), n=5 & $123,80 \pm 1,068$ & $8,18 \pm 0,080$ & $0,86 \pm 0,005$ & $1,80 \pm 0,374$ & $8,88 \pm 0,086$ \\
\hline III, $n=5$ & $125,40 \pm 0,510$ & $8,10 \pm 0,071$ & $0,84 \pm 0,007$ & $2,40 \pm 0,510$ & $9,00 \pm 0,266$ \\
\hline
\end{tabular}

Визначення кількості лейкоцитів $є$ достатньо інформативним показником при вивченні загального функціонального стану організму корів. Результати наших досліджень показали, що загальна кількість лейкоцитів в усіх дослідних групах корів до стимуляції не перевищувала фізіологічно допустимих меж та становила в середньому 8,13 Г/л.

Аналіз основних показників, які характеризують загальний фізіологічний стан організму після нейро-гуморальної стимуляції естрогенами та гонадотропними гормонами дозволяє відзначити, що у порівнянні із отриманими показниками стану крові до стимуляції корів різного рівня продуктивності кількість еритроцитів та лейкоцитів, вміст гемоглобіну, швидкість осідання еритроцитів були вірогідно вищими у тварин як I, так і II (контрольної) групи. Причому, вивчаємі показники у крові тварин II (контрольної) групи до та після стимуляції встановлені відмінності спостерігаються набагато яскравіше.
Нами встановлено, що вища концентрація гемоглобіну в еритроцитах високопродуктивних корів III групи після гормональної стимуляції (125,40 г/л) може свідчить про більш активний механізму регуляції кислотно-лужного балансу та посилення інтенсивності тканинного дихання.

Знання про швидкість осідання еритроцитів (ШОЕ) необхідні для діагностики загальних процесів, інтоксикацій в організмі корів тощо. Показник швидкості осідання еритроцитів взаємопов'язаний з загальною кількістю еритроцитів у крові, а також з білковим спектром її плазми, і його значення залежить від віку, статі, інтенсивності фізіологічної напруги організму тварин тощо. У зв'язку із вищою кількістю еритроцитів у високопродуктивних корів III групи ШОЕ була найвищою і складала 2,00 мм/год, що перевищувало показник низькопродуктивних корів I групи на 0,40 мм/год.

Після проведення гормональної стимуляції показник ШОЕ в крові високопродуктивних корів III групи становив

Вісник Сумського національного аграрного університету 
2,40 мм/год, що було вищим за значення вивчаємого показника в крові перед та після проведення стимуляції відносно двох інших дослідних груп.

Дослідження лейкоцитарної формули, кількості еозинофілів, лімфоцитів, моноцитів доповнює отриманні результати та інформує про активізацію захисних систем в організмі за використання гормональних препаратів для стимуля- ції репродуктивної функції лактуючих тварин. Якщо проаналізувати лейкоцитарну формулу крові піддослідних корів залежно від рівня продуктивності (табл. 3) можна відмітити, що концентрація еозинофілів в крові низькопродуктивних тварин I групи до проведення гормональної стимуляції становила 5,00 мл\%, що на 5 мл\% більше тварин II (контрольної) групи та на 4 мл\% високопродуктивних корів III групи.

Лейкограма крові голштинських корів різного рівня продуктивності

Таблиця 3

\begin{tabular}{|c|c|c|c|c|c|}
\hline \multirow{3}{*}{$\begin{array}{c}\text { Група тварин та рівень } \\
\text { удою }\end{array}$} & Еозинофріли, мл\% & $\begin{array}{c}\text { Паличкоядерні нейтро- } \\
\text { філи, \% }\end{array}$ & $\begin{array}{c}\text { Сегментоядерні нейтро- } \\
\text { філи, \% }\end{array}$ & Лімфоцити, \% & Моноцити, \% \\
\hline & \multicolumn{5}{|c|}{ Фізіологічна норма } \\
\hline & $3-10$ & 6,0 & $10-30$ & $40-77$ & $4-10$ \\
\hline \multicolumn{6}{|c|}{ Перед гормональною стимуляцією } \\
\hline $\mathrm{l}, \mathrm{n}=5$ & $5,00 \pm 0,632$ & $6,00 \pm 0,632$ & $27,00 \pm 2,757$ & $53,80 \pm 2,161$ & $8,20 \pm 0,593$ \\
\hline II (контрольна), n=5 & $10,00 \pm 0,632$ & $6,20 \pm 0,593$ & $30,60 \pm 0,963$ & $44,00 \pm 1,980$ & $9,20 \pm 0,769$ \\
\hline III, $n=5$ & $9,00 \pm 0,490$ & $3,20 \pm 0,522$ & $29,00 \pm 1,356$ & $55,40 \pm 1,459$ & $3,40 \pm 0,876$ \\
\hline \multicolumn{6}{|c|}{ Після гормональної стимуляції } \\
\hline $\mathrm{I}, \mathrm{n}=5$ & $3,80 \pm 0,374$ & $1,60 \pm 0,400$ & $17,00 \pm 1,140$ & $67,60 \pm 1,631$ & $10,00 \pm 0,316$ \\
\hline II (контрольна), n=5 & $6,20 \pm 0,374$ & $4,60 \pm 0,510$ & $26,00 \pm 1,304$ & $59,00 \pm 1,304$ & $4,20 \pm 0,374$ \\
\hline III, $n=5$ & $10,20 \pm 0,860$ & $2,40 \pm 0,245$ & $19,80 \pm 0,663$ & $61,20 \pm 1,828$ & $6,40 \pm 0,510$ \\
\hline
\end{tabular}

Слід звернути увагу, що порівняння показників білої крові у корів до та після нейро-гуморальної стимуляції, спостерігаються певні відмінності між вивчаємими показниками між дослідними групами тварин різної продуктивності. Так, після стимуляції в крові низькопродуктивних корів I групи по відношенню до попередніх показників спостерігалося вірогідне зменшення вмісту еозиносрілів, паличкоядерних та сегментоядерних нейтрофілів.

У той же час концентрація лімфоцитів та моноцитів відповідно на 25,7 і 22,0 \% вірогідно підвищилася. Отриманні результати свідчать про високий рівень гуморального імунітету, а також специфічних та неспецифічних реакцій організму піддослідних корів відповідно їх фрізіологічного стану.

Відносно інших формених елементів крові, можна зробити висновок, що їх значення в усіх дослідних групах голштинських корів відповідали фізіологічно допустимим

параметрам.

Під час проведення аналізу отриманих результатів враховувалося те, що біохімічний склад крові залежить від різних чинників, зокрема, від умов утримання, годівлі, віку, фізіологічного стану тварин. Одним із важливих показників дослідження стану обміну речовин в організмі високо- та низькопродуктивних корів $є$ білковий склад крові. Окрім того, позитивна кореляція надою та вмісту білка в молоці пов'язана з активністю ферментів крові аланінамінотрансферази (АЛТ) та аспартатамінотрансфрерази (АСТ).

Отриманні результати щодо вивчення провідних показників біохімічного стану крові представлені в таблиці 4. Як видно з наведених лабораторних аналізів за фізіологічної норми АЛТ на рівні 0,25-0,65 ммоль/л у крові високопродуктивних корів III групи цей фермент переамінування складав 0,45 ммоль/л, що було вище значення як тварин I так і II (контрольної) груп.

Таблиця 4

Біохімічні показники крові голштинських корів різного рівня продуктивності

\begin{tabular}{|l|c|c|c|c|c|c|c|}
\hline \multirow{2}{*}{$\begin{array}{c}\text { Група тварин та рівень } \\
\text { удою }\end{array}$} & Загальний білок, г/л & Кальцій, ммоль/л & Фосфор, ммоль/л & Глюкоза, ммоль/л & АЛТ, ммоль/л & АСТ, ммоль/л \\
\cline { 2 - 7 } & $75-95$ & $2,0-3,3$ & $0,9-2,5$ & $2,3-4,4$ & \multicolumn{1}{c|}{$0,25-0,65$} & $0,3-0,75$ \\
\hline & \multicolumn{7}{|c|}{ Перед гормональною стимуляцією } \\
\hline I, n=5 & $78,60 \pm 1,166$ & $2,22 \pm 0,107$ & $0,82 \pm 0,037$ & $3,38 \pm 0,150$ & $0,32 \pm 0,021$ & $0,43 \pm 0,013$ \\
\hline II (контрольна), n=5 & $82,00 \pm 1,000$ & $2,25 \pm 0,096$ & $0,96 \pm 0,007$ & $3,60 \pm 0,095$ & $0,43 \pm 0,014$ & $0,51 \pm 0,013$ \\
\hline III, n=5 & $85,40 \pm 0,678$ & $2,33 \pm 0,083$ & $1,00 \pm 0,025$ & $3,78 \pm 0,066$ & $0,45 \pm 0,021$ & $0,54 \pm 0,006$ \\
\hline \multicolumn{7}{|c|}{ Після гормональної стимуляції } \\
\hline I, n=5 & $87,60 \pm 0,678$ & $2,52 \pm 0,058$ & $1,05 \pm 0,020$ & $3,96 \pm 0,068$ & $0,53 \pm 0,010$ & $0,65 \pm 0,016$ \\
\hline II (контрольна), n=5 & $91,60 \pm 1,030$ & $2,76 \pm 0,051$ & $1,15 \pm 0,029$ & $4,00 \pm 0,071$ & $0,62 \pm 0,009$ & $0,68 \pm 0,007$ \\
\hline III, n=5 & $95,20 \pm 0,583$ & $3,24 \pm 0,068$ & $1,28 \pm 0,016$ & $4,34 \pm 0,051$ & $0,62 \pm 0,009$ & $0,74 \pm 0,005$ \\
\hline
\end{tabular}

Наступний показник концентрація глюкози в крові корів до та після гормональної стимуляції показує рівень його використання у якості лабільного субстрату для процесу гліконеогенезу. Як відомо, провідним субстратом для гліконеогенезу у великої рогатої худоби є пропіонова кислота, яка конвертується у глюкозу. Так, концентрація цього енергетичного субстрату в крові голштинських корів до стимуляції складала в середньому 3,59 ммоль/л, у тому числі вірогідно не перевищувала показник тварин I та II груп. В крові високопродуктивних корів III групи концентрація глюкози дорівнювала 3,78 ммоль/л.

Вміст глюкози у крові усіх трьох дослідних груп тварин після гормональної стимуляції відтворної функції знаходився в межах фізіологічної норми. Концентрація глюкози в сироватці крові високопродуктивних корів III групи складала 4,34 ммоль/л, що було вище показника тварин I та II (контрольної) груп на 0,34 і 0,38 ммоль/л відповідно.

Дослідження активності АЛТ та АСТ у сиворотці крові $€$ інформативним для діагностики фізіологічного стану організму корів. В крові високопродуктивних корів III групи ви- 
вчаємі фрерменти перевищували рівень інших двох груп тварин та складали в середньому відповідно 0,62 і 0,74 ммоль/л. Слід зауважити, що за умов підвищення активності трансфераз значення в усіх групах не перевищувало фізіологічні межі, що свідчить про відсутність фізіологічнобіохімічних порушень обмінних процесів в організмі корів.

Одним із діагностичних показників обмінних процесів в організмі високопродуктивних корів $€$ білковий склад крові. Залежно від інтенсивності обміну білків може змінюватися вміст загального білка та його фрракцій. Як показали результати наших досліджень, в сироватці крові високопродуктивних корів III групи загальний білок становив 85,40 г/л, що перевищувало значення вивчаємого показника в інших групах. Вміст загального білка в крові після стимуляції складав 95,20 г/л, що на 11,48 \% було вищим значення до гормональної стимуляції.

Як відомо, фізіологічно обґрунтованим $є$ поступове зниження вмісту кальцію в крові корів до моменту запуску, а його концентрація досягає мінімум після отелення. В крові корів III групи до стимуляції вміст кальцію та фосфрору становив відповідно 2,33 і 1,00 ммоль/л, що перевищувало значення в крові низькопродуктивних корів I групи. Отриманні результати можуть вказувати на активацію процесів кишкової реабсорбції цих елементів та елімінацію їх з кісткової тканини.

Нами був проаналізований рівень мінерального обміну піддослідних корів за вмістом в крові кальцію та фосфору після гормональної стимуляції. Було встановлено, що в групі високопродуктивних корів III групи вміст кальцію складав 3,24 ммоль/л, концентрація фосфору, який $є$ складовою нуклеїнових кислот та фосфоропротеїдів, сягала 1,28 ммоль/л. Проте вміст кальцію та фосфору у всіх без винятку дослідних груп корів відповідав фізіологічній нормі.

Таким чином, на основі отриманих даних, можна зробити висновок, що в організмі корів різного рівня продуктивності впродовж лактаційного періоду відбувається перебудова цілої ланки послідовних фрізіологічно-біохімічних процесів, внаслідок чого відбувається корекція показників крові. Використання біотехнологічного методу нейрогуморальної стимуляції корів позначається на провідних показниках білкового обміну, мофро-функціональному складі крові. Активність ферментів сиворотки крові (АЛТ і АСТ) взаємопов'язана з рівнем молочної продуктивності, відтворювальної здатністю, і може служити інтер'єрним показником при проведенні селекції високопродуктивного стада корів.

Обговорення. Дослідження гематологічних показників має важливе значення в вивченні росту і розвитку сільськогосподарських тварин, так як кров, будучи внутрішнім середовищем організму, що об'єднує між собою органи і тканини, дає можливість з'ясувати багато форм життєвих процесів, протікають в організмі тварин, а також дозволяє направлено впливати на молодий організм, що росте [22, 23].

Однією з важливих фуннцій крові є транспортування кисню до органів і тканин. При дихальної функції гемоглобін, що міститься в еритроцитах, окислюється і доставляє клітинам і тканинам організму кисень і виводить вуглекислоту. Еритроцити беруть також безпосереднє участь в транспортуванні поживних речовин, адсорбуючи їх на своїй поверхні [24].

Загальний фізіологічний стан організму до та після нейрон-гуморальної стимуляції вказує на те, що піддослідні тварини знаходяться у доброму стані. Причому, такі показники як кількість еритроцитів знаходиться в межах фрізіологічної норми та відповідає рівню продуктивності. Якщо у низько- та середньопродуктивних корів цей показник становить у середньому відповідно 6,02 і 6,66 Т/л, то у високопродуктивних він знаходиться на рівні 7,54 Т/л. Щоправда по закінченню гормональної стимуляції концентрація еритроцитів в крові корів різного рівня удоїв хоча і збільшується до 7,908,18 Т/л, але помітної різниці вже немає. При цьому концентрація гемоглобіну в еритроцитах високопродуктивних корів на рівні 125,4 г/л вказує на активацію кислотно-лужного балансу та інтенсифікацію тканинного дихання. Більше того, у цих тварин фрермент переамінування (АЛТ) знаходиться на рівні 0,62 ммоль/л, що підкреслює високу білок-синтезуючу функцію печінки.

Кров високопродуктивних тварин характеризується високою концентрацією глюкозою як до стимуляції на рівні 3,78 ммоль/л, так і після неї - 4,34 ммоль/л. У цей же час і вміст загального білка зростає на $11,5 \%$ і становить у середньому 95,2 г/л.

Під час проведення експерименту всі показники мінерального обміну у крові голштинів були в межах фізіологічної норми та зберігається високий рівень гуморального імунітету.

Висновки. 1. Морфологічні показники крові у тварин всіх дослідних груп знаходяться в межах референтної норми як до, так і після стимуляції охоти та синхронізації овуляції. Загальна кількість лейкоцитів в усіх групах корів до стимуляції становить в середньому 8,13 Г/л, в той час як після стимуляції - 8,81 Г/л.

2. Корови III групи після гормонального обробітку характеризуються активнішим механізмом регуляції кислотнолужного балансу та посиленою інтенсивністю тканинного дихання, про що свідчить концентрація гемоглобіну в їх крові на рівні 125,4 г/л.

3. Дослідження лейкоцитарної формули крові піддослідних тварин вказує, на нормальний стан їх здоров'я. При цьому, концентрація еозинофілів в крові низькопродуктивних тварин I групи до проведення стимуляції естрального циклу становить 5,00 мл\%, а це більше показників тварин II (контрольної) групи та високопродуктивних тварин III групи на 5 мл\% та 4 мл\% відповідно.

4. В організмі піддослідних тварин відсутні фізіолого-біохімічні порушення обмінних процесів, про що свідчить рівень АЛТ і АСТ. При чому, в крові високопродуктивних III групи ферменти переамінування перевищують рівень інших двох дослідних груп в середньому на 0,62 і 0,74 ммоль/л відповідно.

\section{Список використаної літератури:}

1. Аминова А.Л., Юмагузин И. Ф., Фенченко Н. Г., Кхаируллина Н. И., Шамсутдинов Д. Х. Репродуктивный статус коров в зависимости от продуктивности и количества лактаций. Молочное и мясное скотоводство. 2019. Вып. 6, С. $29-31$. Вісник Сумського національного аграрного університету 
DOI:10.33943/mms.2019.6.39674.

2. Amstalden M., Williams R. C. Hypothalamic neuropeptides and the nutritional programming of puberty in heifers. Journal of Animal Science. 2014, issue 92 (8), pp. 11-22.

3. Аминова А. Л., Рамеев Т. В. Влияние Витама на продуктивность и продолжительность сервис-периода коров. Тенденции развития науки и образования. 2018. DOI:10.18411/lj-28-02-2018-65.

4. Bilgen O., Özenç E.. Effects of the Double-Ovsynch Program on some Reproductive Parameters at Different Postpartum Days in Dairy Cows. Kafkas Universitesi Veteriner Fakultesi Dergisi. 2009. DOI:10.9775/kvfd.2010.2072.

5. Бегиев С. Ж., Кагермазов Ц. Б., Темираев Р. Б., Биттиров А. М. Перспективы повышения молочной продуктивности коров черно-пестрой голштинской породы и эффрективность оплаты продукции кормом. Аграрная Россия. 2019, issue 8, pp. 39-42. DOI:10.30906/1999-5636-2019-8-39-42.

6. Гильмутдинов Р. Ю., Ахметзянова Ф. К., Галимуллин И. С. Гематологические показатели коров при раздельном и комбинированном введении концентратов ПРОВЕТЕХ К и ПРОВЕТЕХ П. Научные заметки Казанская государственная академия ветеринарной медицины им. Н. Э. Баумана. Вып. 236 (4), C. 85-89. DOI: 10.31588 / 2413-4201-1883-236-4-85-89.

7. Гайнутдинова Е., Сафина Н., Шакиров С. Совместимость молочной продуктивности и репродуктивной способности коров голштинской породы. Вестник Казанского государственного аграрного университета. 2020. Bып. 15 (2), C. 5-9. DOI: 10.12737 / 2073-0462-2020-5-9.

8. Иванова С. Н. Биохимические показатели крови коров. Вестник Астраханского государственного технического университета. 2018, C. 85-89. DOI: 10.24143 / 1812-9498-2018-1-85-89.

9. Karakaya-Bilen E., Yilmazbas-Mecitoglu G., Keskin A., Guner B., Serim E., Santos J. E. P., Gümen A. Fertility of lactating dairy cows inseminated with sex-sorted or conventional semen after Ovsynch, Presynch-Ovsynch and Double-Ovsynch protocols. Reproduction in Domestic Animals, 2018, isssue 54 (2), pp. 309-316. DOI:10.1111/rda.13363.

10. Кондрахин И.П. Методы ветеринарной клинической лабораторной диагностики. М. : Колос, 384 с.

11. Меньшиков В. В. Клиническая лабораторная аналитика. Агат-Мед, 2002, Вып. 1, С. 115-164.

12. Меньшиков В. В. Руководство по клинической лабораторной диагностике. М. : Медицина, 251 с.

13. Митяшова О. С., Гусев И. В., Лебедева И. Ю. Обмен веществ и репродуктивная функция в послеродовой период у коров-первотелок при введении им экстракта плаценты. Сельскохозяйственная биология, 2017. Вып. 52 (2), С. 323-330. DOI : 10.15389/agrobiology.2017.2.323rus.

14. Романова В. В., Пермиакова П. Ф., Павлова Л. П., Василева Е. С. Оценка коров по основным показателям молочной продуктивности. Тенденции развития науки и образования. 2018, DOI : 10.18411/lj-11-2018-131.

15. Shahzad A. H., Sattar A., Ahmad N., Ahmad I., Nak D., Nak Y. Evaluation of Ovsynch and CIDR + Ovsynch Protocols to Improve Reproductive Efficiency in Lactating Dairy Cows. Pakistan Journal of Zoology, 2019. issue 51(5). DOI :10.17582/journal.pjz/2019.51.5.1607.1614.

16. Stangaferro M. L., Wijma R., Masello M., Granados G. E., Giordano J. O. Profitability of dairy cows managed for first service with the Double-Ovsynch or Presynch-Ovsynch protocol and different duration of the voluntary waiting period. Journal of Animal Science, 2016, issue 94 (5), pp. 612-613. DOl:10.2527/jam2016-1270.

17. Терентьев С. С. Гематологические и биохимические параметры крови коров и телят, рожденных от них с иммуномодуляторной и гормональной стимуляцией. Ветеринар. 3. 2019. C. 3. DOI: 10.33632/1998-698x.2019-3-34-41.

18. Хайруллин Д. Д., Валийллин Л. Р., Овсянников А. П.. Влияние УВМК «Лик-СОЛВИТ» на гематологические параметры крови молочных коров. Ученые записки Казанской государственной ветеринарной академии имени Баумана. 2018, Вып. 235 (3), С. 180-184. DOI: 10.31588 / 2413-4201-1883-235-3-180-184.

19. Хамитова Л. Ф. Синхронизация репродуктивных циклов коров при хроническом бесплодии. Направления развития науки и образования. 2020. DOI: 10.1016 / b978-0-08-100596-5.00706-x.

20. Hutens M. F. Dairy Farm Management Systems: Dry-Lot Dairy Cow Breeds. Reference Module in Food Science, 2016. DOI: 10.1016 / b978-0-08-100596-5.00706-X.

21. Хмельничий Л. М., Салогуб А. М., Шевченко А. П., Хмельничий С. Л., Білоног О. О., Бурлаченко К. Ю., Коваль О. М. Мінливість довічної продуктивності корів української чорно-рябої молочної породи залежно від генеалогічних формувань. Вісник Сумського національного аграрного університету. Серія Твариннитцво, Вип. 10 (20). 2012. С. 12-18.

22. Баймишев М., Баймишев М., Еремин С., Еремин С., Баймишев Х., Баймишев К., Баймишева С. Гематологические параметры коров при применении иммуномодуляторов. Вестник Самарской государственной сельскохозяйственной академии, 2019, Вып. 89-94. DOI: 10.12737 / article_5c876049e9c1a7.23282880.

23.Шаньшин Н. В. Морфо-биохимические показатели крови коров при восстановлении половой цикличности биогенным лекарственным препаратом. Вестник КГАУ, 2020, вып. 3, С. 125-128. DOI: 10.36718 / 1819-4036-2020-3-125-128.

24. Перфилов А. А., Баймишев Х. Б. Воспроизводительные способности коров в зависимости от уровня молочной продуктивности. Вестник Алтайского государственного аграрного университета. № 5 (25), 2006, С. 29 -31.

\section{References:}

1. Aminova, A. L., Yumaguzin, I. F., Fenchenko, N. G., Khairullina, N. I., Shamsutdinov, D. H. (2019). Reproduktivnyj status korov v zavisimosti ot produktivnosti i kolichestva laktacij [Reproductive status of cows depending on productivity and number of lactations]. Dairy and beef cattle breeding, (6), 29-31. (in Russian) doi :10.33943/mms.2019.6.39674.

2. Amstalden, M., Williams, R. C. (2014). Gipotalamicheskie nejropeptidy i programma pitanija telok v period polovogo sozrevanija [Hypothalamic neuropeptides and the nutritional programming of puberty in heifers]. Journal of Animal Science, 92 (8), 1122. 
3. Aminova, A. L., Rameev, T. V. (2018). Vlijanie Vitama na produktivnost' i prodolzhitel'nost' servis-perioda korov [The effect of Vitam on the productivity and duration of the service period of cows]. Trends in the development of science and education. (in Russian). doi :10.18411/lj-28-02-2018-65.

4. Bilgen, O., Özenç, E. (2009). Effects of the Double-Ovsynch Program on some Reproductive Parameters at Different Postpartum Days in Dairy Cows. Kafkas Universitesi Veteriner Fakultesi Dergisi. doi :10.9775/kvfd.2010.2072.

5. Begiev, S. Zh., Kagermazov, C. B., Temiraev, R. B., Bittirov, A. M. (2019). Perspektivy povyshenija molochnoj produktivnosti korov cherno-pestroj golshtinskoj porody i jeffektivnost' oplaty produkcii kormom [Prospects for increasing the milk productivity of black-and-white Holstein dairy cows and the efficiency of payment for forage products]. Agrarian Russia, (8), 39-42. (in Russian). doi:10.30906/1999-5636-2019-8-39-42.

6. Gil'mutdinov, R. Ju., Ahmetzjanova, F. K., Galimullin, I. S. (2018). Gematologicheskie pokazateli korov pri razdel'nom i kombinirovannom vvedenii koncentratov PROVETEX K i PROVETEX P [Hematological parameters of cows with separate and combined administration of PROVETEX K and PROVETEX P concentrates]. Scientific notes Kazan State Academy of Veterinary Medicine Bauman, 236 (4), 85-89. (in Russian). doi: 10.31588 / 2413-4201-1883-236-4-85-89.

7. Gajnutdinova, E., Safina, N., Shakirov, S. (2020). Sovmestimost' molochnoj produktivnosti i reproduktivnoj sposobnosti korov golshtinskoj porody [Compatibility of milk production and reproductive capacity of Holstein cows]. Bulletin of Kazan State Agrarian University, 15 (2), 5-9. (in Russian). doi: 10.12737 / 2073-0462-2020-5-9.

8. Ivanova, S. N. (2018). Biohimicheskie pokazateli krovi korov [Biochemical parameters of the blood of cows]. Bulletin of the Astrakhan State Technical University, 85-89. (in Russian). doi: 10.24143 / 1812-9498-2018-1-85-89.

9. Karakaya-Bilen, E., Yilmazbas-Mecitoglu, G., Keskin, A., Guner, B., Serim, E., Santos, J. E. P., Gümen, A. (2018). Fertility of lactating dairy cows inseminated with sex-sorted or conventional semen after Ovsynch, Presynch-Ovsynch and Double-Ovsynch protocols. Reproduction in Domestic Animals, 54(2), 309-316. doi:10.1111/rda.13363.

10. Kondrahin, I. P. (2004). Metody veterinarnoj klinicheskoj laboratornoj diagnostiki [Methods of veterinary clinical laboratory diagnostics]. KolosS, Moscow (in Russian). Russian).

11. Men'shikov, V. V. (2002). Klinicheskaja laboratornaja analitika [Clinical laboratory analytics]. Agat-Med, 1, 115-164 (in

12. Men'shikov, V. V. (1982). Rukovodstvo po klinicheskoj laboratornoj diagnostike [Clinical Laboratory Diagnostic Guidelines]. Medicine, Moscow (in Russian).

13. Mitjashova, O. S., Gusev, I. V., Lebedeva, I. Ju. (2017). Obmen veshhestv i reproduktivnaja funkcija v poslerodovoj period u korov-pervotelok pri vvedenii im jekstrakta placenty [Metabolism and reproductive function in the postpartum period in first-calf cows with the introduction of placenta extract]. Agricultural Biology, 52 (2), 323-330. (in Russian). doi:10.15389/agrobiology.2017.2.323rus

14. Romanova, V. V., Permiakova, P. F., Pavlova, L. P., Vasileva, E. S. (2018). Ocenka korov po osnovnym pokazateljam molochnoj produktivnosti [Evaluation of the family on the main indicators of milk production]. Trends in the development of science and education. (in Russian). doi:10.18411/lj-11-2018-131

15. Shahzad, A. H., Sattar, A., Ahmad, N., Ahmad, I., Nak, D., Nak, Y. (2019). Evaluation of Ovsynch and CIDR + Ovsynch Protocols to Improve Reproductive Efficiency in Lactating Dairy Cows. Pakistan Journal of Zoology, 51(5). doi:10.17582/journal.pjz/2019.51.5.1607.1614.

16. Stangaferro, M. L., Wijma, R., Masello, M., Granados, G. E., Giordano, J. O. (2016). Profitability of dairy cows managed for first service with the Double-Ovsynch or Presynch-Ovsynch protocol and different duration of the voluntary waiting period. Journal of Animal Science, 94 (5), 612-613. doi:10.2527/jam2016-1270.

17. Terent'ev, S. S. (2019). Gematologicheskie i biohimicheskie parametry krovi korov i teljat, rozhdennyh ot nih s immunomoduljatornoj i gormonal'noj stimuljaciej [Hematological and biochemical parameters of the blood of cows and calves born from them with immunomodulatory and hormonal stimulation]. Veterinarian, 3, 34-41. (in Russian) doi: 10.33632/1998-698x.2019-3-34-41.

18. Hajrullin, D. D., Valijllin, L. R., Ovsjannikov, A. P. (2018). Vlijanie UVMK «Lik-SOLVIT» na gematologicheskie parametry krovi molochnyh korov [Influence of UVMK "Lik-SOLVIT" on hematological parameters of the blood of dairy cows]. Scientific notes of the Kazan State Veterinary Academy named after Bauman, 235 (3), 180-184. (in Russian) doi: 10.31588 / 2413-4201-1883-235-3180-184.

19. Hamitova, L. F. (2020). Sinhronizacija reproduktivnyh ciklov korov pri hronicheskom besplodii [Synchronization of the reproductive cycles of cows with chronic infertility]. Directions of development of science and education. (in Russian) doi: $10.18411 / \mathrm{lj}-$ 02-2020-49.

20. Hutjens, M. F.(2016). Dairy Farm Management Systems: Dry-Lot Dairy Cow Breeds. Reference Module in Food Science, doi: 10.1016 / b978-0-08-100596-5.00706-x.

21. Khmelnychyi, L. M., Salohub, A. M., Shevchenko, A. P., Khmelnychyi, S. L., Bilonoh, O. O., Burlachenko, K. Iu., Koval, O. M. (2012). Minlyvist dovichnoi produktyvnosti koriv ukrainskoi chorno-riaboi molochnoi porody zalezhno vid henealohichnykh formuvan [Variability of lifelong productivity of cows of the Ukrainian black-spotted dairy breed depending on genealogical formations]. Bulletin of Sumy National Agrarian University. Series Animal Husbandry, issue 10 (20), pp. 12-18.

22. Bajmishev, M., Bajmishev, M., Eremin, S., Eremin, S., Bajmishev, H., Bajmishev, K., Bajmisheva, S. (2019). Gematologicheskie parametry korov pri primenenii immunomoduljatorov [Hematological parameters of cows when using immunomodulators]. Bulletin of the Samara State Agricultural Academy, pp. 89-94. DOI: 10.12737 / article_5c876049e9c1a7.23282880.

23. Shan'shin N. V. (2020). Morfo-biohimicheskie pokazateli krovi korov pri vosstanovlenii polovoj ciklichnosti biogennym lekarstvennym preparatom [Morpho-biochemical parameters of blood of cows at restoration of sexual cyclicity by a biogenic drug]. Вісник Сумського національного аграрного університету 
Bulletin of KSAU, issue 3, pp. 125-128. DOI: 10.36718 / 1819-4036-2020-3-125-128.

24. Perfilov, A. A., Bajmishev, H. B. (2006) Vosproizvoditel'nye sposobnosti korov v zavisimosti ot urovnja molochnoj produktivnosti [Reproductive abilities of cows depending on the level of milk productivity]. Bulletin of the Altai State Agrarian University, issue 5 (25), pp. 29-31.

\section{Honchar A.O., PhD in Agricultural Sciences, Dnipro State Agrarian and Economic University Influence of hunting stimulation and ovulation synchronization on morpho-biochemical indicators of Holstain cow blood}

The statute to avenge the results and advances in hematological and biochemical indicators in the blood before the exogenous hormonal stimulation of the reproductive function of Holstein cows of the growth of productivity at the industrial complex. Morphological and biochemical indicators of blood began with a hand before the ear of the scheme of stimulation of hunting and synchronization of ovulation "Ovsynch", and then after it. Formation of the pre-previous groups was carried out in the form of fallow ground and additional milk yield: I group - 25-28 kg, II group (control) - 30-35 kg, III - 40-45 kg. Blood sampling was performed from the tail vein in healthy cows after 15 days after calving (before hormonal stimulation) and for 80 additional hours after calving, if the creatures had already taken off hormone-like stimulating drugs. It was established that the number of erythrocytes in the blood of the blood of the older groups during the preparatory period (before the hormonal processing of the food) to improve the productivity of the milk. Moreover, the indicator of the level of hemoglobin of tvarin in the most recent groups according to the physiological norms. The exogenous introduction of gonadotropic speech into the organism of Holstein barks at the early stage of the period (10-14) cannot be produced until the level of morphological indicators of blood is changed. It was established that there is a high level of blood cells (8.10) and leukocytes (9.0) in the blood of the III group of tvarins, which are small for $41.0 \mathrm{~kg}$ of milk. The quantitative content of total blood protein in animals of all experimental groups was within the physiological norm, but the largest amount (95) was observed in blood samples of group III animals after hormonal stimulation of estrus. At the same time, the level of hemoglobin in these cows was $125.4 \mathrm{~g} / \mathrm{l}$, with a total blood protein content of $95.2 \mathrm{~g} / \mathrm{l}$. Indicators of mineral metabolism in cows of group III indicate the content of calcium and phosphorus at the level of $3.24 \mathrm{mmol} / \mathrm{l}$ and $1.28 \mathrm{mmol} / \mathrm{l}$, respectively. Physiological and biochemical processes in animals of all groups both before and after stimulation of hunting and synchronization of ovulation in the conditions of an industrial complex pass without disturbances, as evidenced by the reference level of ALT and AST, and the highest content of transaminases was observed in cows of group III after hormonal stimulation.

Key words: milk yield, stimulation, synchronization, total protein, erythrocytes, calcium phosphorus.

Дата надходження до редакції: 26. 08.2020 p. 